\title{
ORTHODOX CHURCH ON KAREL FARSKÝ. ON THE BATTLE OF THEOLOGICAL ORIENTATION OF THE CZECHOSLOVAK CHURCH (HUSSITE) IN THE 1920s
}

\author{
Marek Pavel \\ Doctor of Philosophy and Pedagogy; Professor; Professor Emeritus, Department of History, Faculty of Arts, \\ Palacký University, Olomouc \\ Email: pavel.marek@upol.cz \\ Scopus Author ID: 35178301400 \\ http://orcid.org/0000-0001-7578-0783
}

One hundred years have passed since 1920 and the 'Czech schism', which is considered to be the foundation of the national Czechoslovak (Hussite) Church. It was created as a result of the reform movement of the Catholic clergy after the end of the Great War and the constitution of an independent Czechoslovak Republic on the ruins of the Habsburg Monarchy. The clergy, who were dissatisfied with the position of the Catholic Church in the empire and with some matters of the Church life and priests that had not been addressed in the long term, set out a programme for the reform of the Catholic Church in Czech lands. His demands were directed towards the autonomous position of the church, the introduction of the national language into services, the democratisation of the organisation of the church, and the reform of clerical celibacy. After the Roman Curia rejected the proposals, the reform movement's radical wing decided to leave the church and form a national church. However, its establishment wasn't sufficiently prepared and all fundamental issues of its existence, including its doctrine, were only solved after establishing the church. Two opinion wings were formed on this matter in the church. The first sought to accept the doctrine of the Eastern churches, the second, led by the future patriarch Karel Farský, set out the concept of a modern $20^{\text {th }}$ century church. There was a fierce ideological fight between the two groups to promote their own concept until 1924. The aim of this study is to reflect the behaviour and activities of K. Farský by the spokespersons of the Orthodox-oriented section in the church.

Keywords: Karel Farský, Czechoslovak Hussite Church, Roman Catholic Church, Orthodox doctrine, theological modernism, church reform, national church, Czech lands, 1920s.

Formulation of the issue. One hundred years have passed since 'Czech Schism' in January 2020, since the establishment of the National Czechoslovak (Hussite) Church, whose founding (January $8^{\text {th }}, 1920$ ) was the result of an unsuccessful attempt by the Czech Catholic clergy to reform the Roman Catholic Church in the newly established Czechoslovak Republic (1918). The Church went through a rather complicated search for its own identity, which among other things, is reflected in the fact that to date there hasn't been an author that would prepare a historical synthesis of its development over the past hundred years objectively and on a high professional level. [Jurek] The same deficit is felt in relation to one of the most significant and the most important personalities in the history of the Czechoslovak (Hussite) Church, ThDr. Karel Farský, its founder and first patriarch. The conclusiveness of this thesis convincingly illustrates the attention this figure enjoys in ecclesiastical historiography. His activities and merit in the Church are evaluated primarily by shorter studies and articles published in the professional and popular press. There are few monographs mapping Farský's life and work, created over time as if each of the next generation of writers felt the need to take a stand on him and express what was current and inspiring from his work at that time. However, even in this case we are waiting for an author who will deal with the abovementioned, at first glance quite tempting but also very demanding topic, without deficits and a certain conformance which burdened the historians and authors of Farský's biographies so far due to their intellectual, emotional or other links to 'their' ecclesial and religious community.

Study objectives. The aim of our essay is not a critical review of the existing literature on the history of the Church or the personality and work of Farský, even though these topics are a key challenge for a historian. We want to respond to the fact that the evaluations of Farský as a crucial figure in the interpretation of the early phase of the history of the Church (the patriarch died in 1927) in the works of authors, mostly theologians or clergy, tied to the Czechoslovak (Hussite) Church are not fully balanced. The personality in their conception is often almost sacralised. All his positives, advantages and merits are found correctly. However, at the same time, the same authors ignore the critical remarks and comments on his actions. We are convinced that the concealment or omission of the negatives, weaknesses, errors and mistakes that every person makes in their life is a violation of the ethics of scientific work and signals deficits in mastering the methods and techniques of a historian's work. Ultimately, such an approach not only devalues the author's efforts, but also has an adverse impact on the character's assessment of their interest; the writer distorts reality. In this paper we want to try and reflect Farský's character or his behaviour during the socalled Orthodox crisis period in the Czechoslovak (Hussite) Church from 1920 to 1924, by the Orthodox opposition.

Analysis of sources and literature. The study largely relies on archival collections stored in the church archives of the Czechoslovak, Orthodox and Catholic

(c) Марек П. 
Churches. The Central Archive and the Czechoslovak Hussite Church Museum in Prague (ÚAMCČH) holds collections for the study of the reform movement of the Catholic clergy, especially its radical factions acting under the auspices of Ohnisko ('Focus') and Klub reformních kněží Jednoty katolického duchovenstva ('Club of Reform Priests for the Unity of the Catholic clergy') associations. It makes it possible to study the activities (minutes from meetings) of the Church's central bodies (committee and consistory) and its leaders. Especially valuable are correspondence units containing letters of all protagonists of the Church - K. Farský, B. Zahradník-Brodský, M. Pavlík, J. Žídek, Emil DlouhýPokorný, František Kalous, Albín Polešovský and others. The personal collection of Bishop M. Pavlík-Gorazd, located in the registry of the eparchy of Olomouc-Brno for the Orthodox Church in Czech Lands and Slovakia (APC), is a rich source of information. It contains a rich bishop's correspondence with Farský and Žídek, but also with other Czechoslovak Church priests, and valuable evidence of his contacts with Dositej (Vasić) and other Serbian Orthodox Church leaders. Recently, the personal collection of Žídek was found again and deposited in the Archive of the Olomouc Archbishopric (AAO); according to the priest's work place, it is referred to as the Chudobín archive. Žídek, as an Orthodox-oriented clergyman, was one of the greatest critics of Farský in the Czechoslovak Church. In addition, we used materials from the personal collection of B. Zahradník-Brodský, deposited in the Literary Archive of the Monument of National Literature in Prague (LA PNP). The National Museum Archives in Prague (ANM) with the collection of the Unity of the Catholic Clergy and the personal collection of the secretary of this association, Jan Žížala, are also important for studying the reform movement.

For the study of the reform movement and the beginnings of the Czechoslovak (Hussite) Church in connection with the so-called Orthodox crisis, the periodicals from 1918 to 1924 are important, enabling to reconstruct the course of disputes between individual groups and movements in the Church. Especially valuable are the 'Journals' of the clergy unions based in Prague, Brno and Olomouc. Pavlík founded the newspaper Právo národa ('The Right of the Nation') in 1918, which was later transformed into Český zápas ('Czech Fight') and the Olomouc periodical Za pravdu ('For the Truth') became the Orthodox faction's spokesman. The reaction of the Pope and the Roman Curia to the church and religious crisis in Czechoslovakia makes it possible to study archives stored in the Vatican archives. The most important ones are now available in editions prepared by Prague researchers [Czechoslovakia and the Holy See II/1, 2013].

Our chosen topic has not been discussed in literature yet. The author touched on this issue in a broader context in his previous research work on the reform movement of the Catholic clergy and the history of Czech Orthodoxy [Marek, 2000, 2005, 2007, 2010, 2015, 2017, 2019, Schulze Wessel, 2011, s. 117-176]. The personality of Farský was monographed mainly by church historians M. Kaňák [Kaňák, 1951], V. Kadeřávek and Z. Trtík [Kadeř́vek, 1982] and M. Chadima [Chadima, 2017], while the documentary value is still maintained by Karel
Farský's Collection published shortly after his death [Collection, 1928]. In addition to numerous published magazine articles, including at least two older ones written by his colleague F. Kalous [Kalous, 1937] and B. Pešek [Pešek, 1939], Farský's own literary work is also important [Farský, 1919, 1920, 1921]. On the occasion of the $90^{\text {th }}$ anniversary of Farsky's death, the Church published a collection of articles expressing the attitudes of the present generation of priests to his life work [Butta, 2017]. Farský's character and activities are also reflected in works on the history of the Church [Urban, 1938; Němec, 1975; Hrdlička, 2007; Schulze Wessel, 2009; Jurek; Hraba] and the Catholic clergy's reform movement [Cinek, 1926; Němec, 1968; Huber, 1990; Marek, 2000; Frýdl, 2001; Šmíd, 2017].

Research results. As mentioned above, the figure of patriarch Farský is the centre of attention for many authors and is therefore well-known. Therefore, we will only pay attention to it here in the extent necessary to understand our interpretation. He came from the poor Podkrkonoší region (born July $16^{\text {th }}, 1880$ in Škodějov, died June $12^{\text {th }}, 1927$ in Prague), from a large and very devout Catholic family. When he lost his father at the age of 12 , he was able to educate himself with the financial support of his uncle, priest Josef Farský (1851-1910). He was one of the recognised and capable clergy, which was confirmed by his function as a spiritual, later rector of the Prague priest seminary and the canon of the Chapter of St. Peter and Paul at Vyšehrad (1902-1910). It was thanks to the patronage and intercession of his uncle that the young chaplain found himself as an adjunct at the Faculty of Theology of Charles-Ferdinand University in Prague two years after his priest ordination (1904) and stood in for ill Professor ThDr. J. L. Sýkora in lectures from the New Testament. A four-year teaching career at the university enabled him to continue his education (he became a Doctor of Theology in 1909) and verified his personal prerequisites. He had to leave the faculty in 1910 and worked as a religion teacher at secondary schools and grammar schools in Prague and Plzen̆ for the following decade until 1919. It seems that the nonextension of employment at the university was the first step on the road to breaking away from the Catholic Church. He had a hard time dealing with the decision and felt it as personal hurt. Apparently, he had paid for his slightly arrogant, and little respectful behaviour towards the superior church fathers, marked by a high selfesteem, a critical attitude associated with an ironic appraisal of things and the introversion, which did not conceal high ambitions. In addition, he was perceived by the church hierarchy as a hidden supporter of Catholic modernism, despite the fact that he did not engage in the activities of Czech modernists and first draw attention to himself in these circles in early 1919. Perhaps the loss of the protective hand and the 'retaliation' for his uncle's favouritism after his death also played a role.

The years of the Great War had been referred to by Farský as a turning point in his life; he described them several times in his literary work [Farský, 1919; 1920; 1921]. At that time, like many other Czech (although not only Czech) Catholic priests and believers, he underwent a spiritual crisis. Although he was an educated and capable intellectually based priest, he began to fluctuate 
in dogmatism within himself and failed to reconcile his faith in God with the rational perception of the world and its material nature. Simultaneously, he had to absorb new impulses connected with the penetration of liberal and socialist movements into Czech society, which went through the final stage of its emancipation and was looking for a future of constitutional law for itself; the Czech nation lived under a multinational and nationally unfair Habsburg Monarchy. From these circumstances a critical relationship was born to the Catholic Church and its Roman (Vatican) centre, to the close connection of the Catholic Church with the monarchy (to the so-called Austrian Catholicism) and the idea of creating a national church. Farský at the end of the war represented a Catholic priest with an extremely critically acclaimed assessment of the Catholic Church; we can only speculate with regard to what extent his personal conflicts with the Archbishops of Prague (as he himself claimed) contributed to his attitude and the foundation of the Czechoslovak Church [Chadima, pp. 35-41]. A question is what really was behind his decision from the end of 1918 not to apply for the prestigious position of the town priest in Plzeň, which he was originally interested in.

After the independent Czechoslovak Republic has been established, Farský became involved in the efforts of the Czech Catholic clergy to reform the Catholic Church in the country [Cinek; Němec, 1968; Huber, 1990; Marek, 2000; Frýdl]. He soon left the post of catechist and became an official at the Ministry of Education in Prague. He was politically involved in the right-wing Kramáŕr's National Democratic Party and took the lead of a radical stream of reform movement in the second half of 1919, which, via facti, was directed at provoking a quarrel with the Catholic Church and a constitution of the national Czechoslovak (Hussite) [Urban, 1938; Němec, 1975; Marek, 2005; Schulze Wessel, 2009; Šmíd, 2017]. Farský belonged to the group of founders of the Church and became its informal and then formal leader (until his untimely death) in the post of the first patriarch (1924-1927). At the time of its founding, there was a consensus that the Church would remain Catholic in terms of doctrine and that the reform would concern the organisation, liturgical and disciplinary spheres. However, this unity of opinion soon disintegrated and the Church went through a period of searching for its own identity basically until 1924. It primarily dealt with the doctrinal system, but all fundamental questions had to be decided in order to be considered a standard church. Initially, it seemed to support Eastern churches and become Orthodox. However, Farský had already presented a vision of building a modern $20^{\text {th }}$ century church in 1920 [Marek, 2015, p. 10-11]. The Church was divided into two parts in terms of opinion, and the supporters of these concepts fought hard to enforce their own doctrinal system. The Orthodox and modernist visions were theologically incompatible with each other.

The leading figure in the Czechoslovak Church to accept the Orthodox doctrine and to establish contacts with the Serbian Orthodox Church, which was supposed to guarantee its path to autocephality, was also the originally Catholic priest and writer Bohumil Zahradník-
Brodský (1862-1939) [Marek, 2017]. He was supported in Moravia by clergyman Josef Žídek (1889 - 1968) from Chudobín [Marek, 2010] and his colleague from nearby Litovel, Karel Koudelka. This Orthodox group of priests expanded to include Matěj Pavlík-Gorazd (1879 1942) in 1921 [Marek, 2019]. He became the first bishop of the Czechoslovak Church and received the laying on of hands from the Serbian Orthodox Church. He took the position of spokesman for the Orthodox faction in the Czechoslovak Church and Farský's main opponent. Priest Josef Leixner (1893-1970) was at his side, while merchant František Reyholda (1879-1933), one of the few laymen in the movement, was the loudest to enforce the adoption of the Orthodox doctrine by the Church in Prague. The list of Farský's most prominent critics includes priest Emil Dlouhý-Pokorný (1867-1936) [Marek, 2007] and Rudolf Pařík (1889-1961), subject to the fact that they did not join the Orthodox Church, but agreed with Farský's opponents on many issues.

Farskýs image in the Orthodox Czech community operating within the Czechoslovak Church was formed on the basis of comments and assessments of the future patriarch in four areas. (1) Farský as the main organiser of the Church. (2) Farský as a theologian-modernist. (3) Farský's relation to the Orthodox Church doctrine and its followers and representatives. (4) Farský as a man. It should be noted at the beginning that there was no contact between Farský and his opponents and they didn't know each other until 1918. They were only connected when they joined the reform movement, so their relationship developed and modified over time. In all cases, the initially friendly relationship turned into a critical mutual refusal, or open or hidden hatred. Now let's take a more detailed look at individual complaints, statements and attitudes.

We've already mentioned above that Farský profiled himself in 1919 as a leader of a group of radicals in the reform movement. He initiated an oath of loyalty to the priests of the programme, its implementation without compromise and at all costs, even schism in January. Via facti signalled that the establishment of a new church was a matter of a few weeks in the second half of the year. But embarrassment came when it was proclaimed in early January 1920. Most of the leading figures were frightened and backed off. The excommunication of founders made it impossible to fulfil the original intention of keeping the new church Catholic. There was a problem with doctrines. They didn't have bishops and a church which would perform the laying on of hands. The transition to the Czechoslovak Church meant a loss of financial security for the priests and, residence for most of them. Therefore, they hesitated and the Church didn't have as many clergy as it needed. There were difficulties with the space for worship, apart from the area of liturgy itself and ceremonies. The Church wasn't officially recognised by the state administration, had no constitution, couldn't establish religious communities, etc. These and other facts shown that the radical wing of the reform movement underestimated the preparation of the founding of the Church. It didn't solve fundamental questions to the point where a standard church could be established. It's understandable that the Orthodox opposition had rightly and wrongly blamed Farský for 
this situation. Of course, many shortcomings in the internal functioning of the Church had objective causes, but critics rightly saw that he didn't behave as a true leader and didn't follow the goal with decisiveness and vigour. For example, he hesitated to give impetus to its establishment on December $31^{\text {st }}, 1919$, a week before the founding of the Church. He argued that he would be involved in the founding, but then retreated to pursue other interests. He was criticised for the fact that, as chairman of the church committee, he wasn't cautious in admitting and not dampening eccentricities, violence and brawling among believers, which discredited the Church in the eyes of both the government and the general public, and reflected negatively on the Church. Later, he was accused of having problems with adhering to resolutions of its bodies, meetings and congresses, although building the Church on democratic principles. He allegedly had deficits in the area of communication with the collective leadership of the Church. The situation eventually resulted in his temporary formal exclusion from the managing structures, but he was already in such a strong position that his opinion remained decisive for making decisions. Before the founding of the Czechoslovak Church, Pavlík didn't consider Farský a suitable person to take over its management. He favoured the former Premonstratensian, member of the Vienna Imperial Council and the first Czechoslovak parliament, Isidor Zahradník (1864 1926), as the most suitable candidate for this post. Farský had an unquestionable position in the Czechoslovak Church since 1923, which was further consolidated after the secession of Gorazd's Orthodox wing. He maintained this position until his death, and the Church built a cult of the founder and leader around him, which it continues to address today.

However, the most serious reproach was directed at Farský because of his indecision, fumbling and improvisations about the doctrine. Being a leader of the Church, he was responsible to the members and the public for not having a clear creed. We can prove that Farský didn't essentially enforce a consistent breakup with Rome in the period just before the Church was founded. The reform movement leaders wanted to adopt the concept of a union, autonomous Catholic Church, led by a Czech patriarch and to modify the doctrine in only a few significant details. Therefore, Farský himself didn't present a vision of any new church and apparently didn't formulate it. The situation only changed after January $8^{\text {th }}$, 1920, after the establishment of the Czechoslovak Church, at a time when it was necessary to solve practical questions of everyday life and functioning of the Church. There was a period of search for a subject that would help the new Church to overcome its early phase, facilitate establishment and support it, facilitate problem-solving and patronage. Here, one must look for the motives of Farsky's conversations with representatives of a number of churches (Old Catholic, Anglican, Orthodox, Methodist Episcopal Churches), in which the question of the future doctrinal direction of the new Church was naturally crucial. Farský knew from experience that establishing closer ties with one of the established churches inevitably required either taking over its doctrines or at least theological consensus.
However, this reality collided with his idea of the freedom, independence and autonomy of the Czechoslovak Church, which was one of the pillars of the secession of radical faction of the Catholic Church reform movement and the constitution of a new ecclesial community. Farský set himself against the Roman Pope, who in his conception restricted, misunderstood and harmed Czech Catholics for centuries. Therefore, the Czechs must free themselves from Rome and create a church suited to the nature of the nation and its religious reformation past, reflecting the shifts in knowledge and thinking that civilisation has undergone from the Middle Ages to the present. In other words, he quickly realised that none of the existing bearers of a theological system offered what the Czechoslovak Church was looking for. It wasn't a suitable or acceptable partner for it which would accept its requirements. In this situation, he saw the optimal and de facto only way out for the Czechoslovak Church in the formulation of its own, original doctrine. He summed up this idea in an ambitious and idealistic slogan based on the ideas of Czech messianism: the creation of a modern $20^{\text {th }}$ century church. He wanted to offer its theological and organisational model to the whole world [Marek, 2015, p. 10-11].

Farsky's concept, in line with the euphoria that prevailed in Czech society after the constitution of the Czechoslovak Republic, met with a clear disagreement in the circle of priests inclined to Orthodoxy. They did not see anyone in the Czech theological environment who could handle such a task. When Farský, in collaboration with clergyman František Kalous (1881-1965), attempted and published the so-called Czechoslovak Catechism in 1922, he launched an avalanche of criticism that streamed and sounded literally from all sides. Critics agreed that Farský had gone too far and that his new doctrine had moved away from Christian principles [ÚAMCČH, Gorazd R. Paříkovi, 17. 7. 1924; ÚAMCČH, Gorazd to R. Pařík, 17 July 1924]. 'Farský rode into the waters of pantheism' [APC, Gorazd A. Paškovi, b. d.; APC, Gorazd to A. Pašek, b. d.]. His teachings had the same features that we could identify in Arianism, Pelagianism and Unitarianism. [Pařík, 1923] 'Reason cannot be a measure and a determinant to the values of God' [ÚAMCČH, Gorazd K. Farskému, 7. 8. 1923; ÚAMCČH, Gorazd to K. Farský, 7 August 1923]. Farský 'empties the ideological content of the Christian faith with his rationalism' [Pařík, 1923]. 'The Doctor throws articles of faith like a ball and begins to dictate what is to be believed in and what is not. He establishes his 'doctrine' and demands that priests accept it. I believe that we priests don't want dogmatic doctrine to be touched so recklessly' [LA PNP, J. Žídek B. Zahradníkovi, 21. 8. 1920; LA PNP, J. Žídek to B. Zahradník, August $\left.21^{\text {st }}, 1920\right]$. 'Dr. Farský does not stop at dogmas, or at the Holy Scripture. He deletes it as necessary' [LA PNP, J. Žídek B. Zahradníkovi, 2. 12. 1920; LA PNP, J. Žídek to B. Zahradník, December $2^{\text {nd }}$, 1920]. 'Farský's Catechism is the poorest book ever written in this field. [...] The Czechoslovak Church is an ill-conceived daring feat of incapable and empty heads that will lead nowhere and cannot do anything. [...] The Czechoslovak Church has forgotten that Christianity is 
not a sauce and patchwork, but the truth that church cannot be built on a political slogan of freedom of conscience so that everyone under Christianity could think what they wanted' [Čeští bratři... 1923, s. 3; Czech Brothers against the Czechoslovak Church, Lidové listy, 1923, v. 2, no. 29 , February $6^{\text {th }}$, p. 3].

Although media tensions broke out around Farský's Catechism at the time of its publication and his followers supported him, today theologians of the Czechoslovak Church, which, after several decades of searching for their own doctrinal system, is among Protestant denominations, agree with Farský's critics. As a theologian, Farský didn't create a new doctrine, but criticised the Catholic Church doctrine from positions of rationalism, omitting some articles from it, supplementing other or creating new ones. The opposition saw these interventions as an expression of exaggerated self-confidence without proper erudition and disproportionate ambitions to become a great church reformer. It considered them inappropriate and hastily hurried experiments moving the Church towards a sect and free-thinking. It came to the conclusion that 'he is led astray and not far from disloyalty' [APC, J. Žídek M. Pavlíkovi, 23. 8. 1920; APC, J. Žídek to M. Pavlík, August $23^{\text {rd }}$, 1920]. It seems that Farský, with his disposition, was closest to practical theology [Butta, 2005] and church history, which he interpreted in a pragmatic way in order to justify the establishment and existence of the Czechoslovak Church.

The same sharp criticism as in the case of theological modernism fell on Farský's head for his relation to Orthodoxy. In the early phase of the Church's existence, he didn't openly define himself against the Eastern ecclesial community and, after establishing its contact with the Serbian Orthodox Church, led negotiations with it on cooperation. However, it seems that after the first meeting with Dositej (Vasić, 1887-1945) in Karlovy Vary in the spring of 1920 [Marek, 2020, s. 51], he began to look at the possibility of establishing a closer connection between the Czechoslovak Church and Orthodoxy with scepticism and preferred other alternatives. Although signed under the request (the socalled first memorandum) to send the Orthodox mission to Czechoslovakia from September 1920, he internally disagreed with it, which reflected in the first deeper crisis in the Church the following year. He refused to accept Niceno-Constantinopolitan Creed as the creed of the Czechoslovak Church and the conclusions of the first seven ecclesiastical councils, which were to remain unchanged in the future. He disagreed with the agreement with the Serbian Orthodox Church, which was to ensure the Czechoslovak Church to transform into a full-fledged autocephalous unit of the community of Eastern churches. He demanded that the Serbian Orthodox Church consecrate its bishops without further theological commitments and conditions [ZA, K. Farský Zemské radě starších, 28. 2. 1924; ZA, K. Farský to the Elders Provincial Council, February 28 $\left.{ }^{\text {th }}, 1921\right]$. When he didn't enforce his vision in the Church and had to obey the majority's opinion, he began discrediting the Orthodox faith and the Orthodox Church publicly at church meetings and in its press. He began to call the Dositej's mission unnecessary and put obstacles in its activities. He finally managed to thwart cooperation with the Serbian Orthodox Church in 1922, and Dositej ended his mission in relation to the Czechoslovak Church. For Farský, the Orthodox liturgy was unacceptable, especially due to its length. He coincided with all Czech reform clergy without exception in this matter. Secondly, the alleged obsolescence in Farský's mind was a major obstacle to the Orthodoxy option, speaking directly about the mustiness and pre-crisis situation that is contrary to modern times. The third barrier was represented by his connection with the national state policy. He wrote to Bishop Gorazd (Pavlík) on Orthodoxy: 'You will work on its reformation. In my opinion, this idea is as illusory as a project to reform the Roman Church; both are irreformable. For to undertake a reformation in Orthodoxy, which you may have in mind, would mean asking it to renounce itself' [ÚAMCČH, K. Farský Gorazdovi, 18. 8. 1924; ÚAMCČH, K. Farský to Gorazd, August $\left.18^{\text {th }}, 1924\right]$.

We can perceive the criticism of Farský by the Orthodox Church members within the Czechoslovak Church concerning the issue of organisational management and especially theological views as an insight from ideological opponents seeking to promote their own vision and seeking arguments for agitation [Učení náboženské; Základy víry; Tonzar]. However, in our opinion, their observations and assessments based on their own experience in dealing with him cannot be downplayed and only interpreted as a result of a fight for the theological direction of the Czechoslovak Church. They show that the future patriarch was also just a human being, with all the merits, but also mistakes and shortcomings. The epistolographic material created by members of the Orthodox opposition offers a wide range of statements concerning Farskýs character and personality traits. However, summarising it in one unit may be counterproductive, contrary to the aims of our study. Therefore, we will try to sort them and only point out those that occur most often.

The opposition perceived Farský's great self-esteem as most painful, which turned into a tendency towards authoritarianism and domination not permitting discussion or creating room for a different view. It saw him as a suspicious secretive person who listened little to people. He wasn't honest in negotiations, changed his attitudes in different situations and deliberately gave unclear opinions. He responded to arguments with ironic ridicule, instead of defending his point of view and patiently and materially disproving his partner's opinion. He rejected any criticism of his actions. He often intimidated his opponents and resorted to repression. The deficits in Farský's communication were accompanied by his behaviour's unpredictability, non-compliance with agreements, and the tendency to intrigue and to incite one against another. B. Zahradník-Brodský commented resignedly on his turbulent cooperation with Farský: 'Those who have not fought with Dr. Farský themselves will not believe that it gets on one's nerves. He would have worn me out...' [APC, B. Zahradník Gorazdovi, 28. 3. 1924; APC, B. Zahradník to Gorazd, 28 March 1924]. Reyholda embodied his experience in a strong statement: 'We know what a liar Dr. Farský is' [APC, F. Reyholda Gorazdovi, 28. 4. 1923; APC, F. Reyholda to Gorazd, 
April $\left.28^{\text {th }}, 1923\right]$. Given that this experience was gained in the context of seeking optimum doctrine for the Czechoslovak Church, it is no wonder that the writers' diction was often radical: 'These matters oppress us very much and I would compare them to a rock standing in our way. We were afraid to move it and bypass it. Well, the rock is inanimate. Therefore, my comparison would be too mild. A dragon, cruel, wild dragon prevented our development, did so much damage that even a fairy tale would not allow the damage to be described. You know who it is. It's Farský. [...] A person who doesn't belong to the Church couldn't remain in the Church and must stand outside it. [...] All the dirt from Farský should be collected in one tub and, if necessary, shown to the people to show what an unscrupulous man wanted to rule the Church. Do not act somewhat aggressively, but defend with all our strength. Every priest must be united, organised. Let him join our organisation and take a stand on Farský...' [LA PNP, J. Žídek B. Zahradníkovi, 4. 10. 1921; LA PNP, J. Žídek to B. Zahradník, October $4^{\text {th }}$, 1921].

Research conclusions. 1924 is undoubtedly one of the important milestones in the history of the
Czechoslovak (Hussite) Church. The departure of the Orthodox wing from the Church after Bishop Gorazd (Pavlík) concluded that he was unable to resist the pressure by Farský's modernists on his posts created conditions for its stabilisation, ideological unification and completion of organisational construction. Farský convened the first assembly of the Czechoslovak Church, which confirmed him as a patriarch and ended the socalled Orthodox crisis. Subsequently, he directed the further building of the Church until his untimely death. Our research focused on the reflection of his behaviour from 1920 to 1924, and in our opinion quite unequivocally proved that the tension that accompanied the development of the Church as a result of a dispute between both mutually theologically incompatible movements was not in the interests of the spirituality of clergy or believers who decided to break up with the Catholic Church. The Orthodox faction perceived Farský critically and the image it created about him could not be fully objective. On the other hand, its existence should be a challenge to review the equally one-sided view created by its supporters.

\section{References}

APC Olomouc, f. M. Pavlík-Gorazd, k. Biskup Gorazd, korespondence, 20. léta, CČS - dopis biskupa Gorazda A. Paškovi, b. d. [APC, Gorazd to A. Pašek, b. d.].

APC Olomouc, f. M. Pavlík-Gorazd, k. Biskup Gorazd, korespondence, různé - dopis J. Žídka M. Pavlíkovi, 23. 8. 1920. [APC,

J. Žídek to M. Pavlík, August 23rd, 1920].

APC Olomouc, f. M. Pavlík-Gorazd, k. Korespondence biskupa Gorazda s B. Zahradníkem-Brodským, dopis B. Zahradníka biskupu Gorazdovi, 28. 3. 1924. [APC, B. Zahradník to Gorazd, 28 March 1924].

APC Olomouc, f. Matěj Pavlík-Gorazd, k. Biskup Gorazd, korespondence, různé - dopis F. Reyholdy biskupu Gorazdovi, 28. 4. 1923. [APC, F. Reyholda to Gorazd, April 28th, 1923].

Butta, T., 2019. Církev československá husitská a její cesta dějinami s Kristovým posláním. K 100. výročí, Praha: Církev československá husitská, $92 \mathrm{~s}$.

Butta, T. a kol., 2017. Karel Farský. Sborník věnovaný 90. výroči Karla Farského, modernistického kněze, učitele a patriarchy cirkve československé husitské, Praha: Církev československá husitská, $176 \mathrm{~s}$

Butta, T., 2005. Uvedeni do bohoslužebné teorie a praxe v Církvi československé husitské. Prakticko-teologický výklad liturgie podle patriarchy Karla Farského, Praha: Karolinum, $101 \mathrm{~s}$

Cinek, F., 1926. K náboženské otázce v prvních letech naši samostatnosti 1918-1925. K ideovému vývoji církve československé Hnutí pravoslavné v Československu. K situaci českobratrského protestantismu. Dodatek, Olomouc: Lidové tiskařské závody, $315 \mathrm{~s}$ Československo a Svatý stolec: od neprátelství ke spolupráci (1918-1928), I. Úvodní studie, 2012; eds. M. Pehr, J. Šebek, Praha: Masarykův ústav a Archiv Akademie věd ČR, 229 s.

Československo a Svatý stolec, II/1. Kongregace pro mimořádné církevní záležitosti (1919-1925): výběrová edice dokumentů,

2013; eds. P. Helan, J. Šebek, Praha: Masarykův ústav a Archiv Akademie věd ČR, 307 s.

Československo a Svatý stolec, III. Diplomatická korespondence a dalši dokumenty 1917-1928: výběrová edice, 2015; eds. M.

Šmíd, M. Pehr, J. Šebek, P. Helan, Praha: Masarykův ústav a Archiv Akademie věd ČR, v.v.i., 608 s.

Čeští bratři proti československé církvi, Lidové listy, 2, 1923, č. 29, 6. 2., s. 3. [Czech Brothers against the Czechoslovak Church,

Lidové listy, 1923, v. 2, no. 29, February 6th, p. 3].

Devadesát let Církve československé husitské. Sborník, 2010; eds. Z. Kučera, T. Butta, Praha: Církev československá husitská -

Náboženská obec Církve československé husitské v Praze 1, 408 s.

Farský, K., 1919. Český problém církevní, Praha: Dr. Ant. Hajn, 35 s.

Farský, K. (= Nemo, P.), 1919. Papežství a národ český, Praha: B. Kočí, 97 s.

Farský, K., 1920. Z pode jha. Vznik církve československé, Praha: Klub reformního duchovenstva, $58 \mathrm{~s}$.

Farský, K., 1921. Přelom. Vzpomínkové feuiletony k dějinám církve československé z r. 1918-1920, Praha: vlastním nákladem, $124 \mathrm{~s}$.

Frýdl, D., 2001. Reformni náboženské hnutí v počátcích Československé republiky. Snaha o reformu katolicizmu v Čechách a na Moravě, Brno: L. Marek, $219 \mathrm{~s}$

Havelková, K., 2010. Prvni tři patriarchové Církve československé husitské, Praha: Husitská teologická fakulta, rkp. diplomové práce, $80 \mathrm{~s}$.

Hraba, V., 2017. Vira, naděje, láska: počátky, vývoj a současnost Církve československé husitské, Hradec Králové: Královéhradecká diecéze Církve československé husitské, $49 \mathrm{~s}$.

Hrdlička, J., 2015. ThDr. Karel Farský a Československá národní demokracie (ČsND) 1918-1920, Theologická revue 86, č. 1, s. $82-88$.

Hrdlička, J., 2016. Dr. Karel Farský a jeho teologie českých dějin, Historica Olomucensia, sv. 50, s. 179-192.

Hrdlička, J., 2007. Život a dilo prof. Františka Kováře: př́běh patriarchy a učence, Brno: L. Marek, 523 s. 
Huber, K. A., 1990. Klerusverbände in den böhmischen Ländern. Die tschechischen Priestenvereine, Archiv für Kirchengeschichte von Böhmen - Mähren - Schlesien, 11, s. 7-48.

Chadima, M., 2017. Dr. Karel Farský - prvni patriarcha Cirkve československé (husitské), Hradec Králové: Královéhradecká diecéze CČSH, $204 \mathrm{~s}$.

Janota, V. 1929. Je to jedno? Rozdíl mezi církví československou a řimsko-katolickou: rozbor katechismu církve československé, Rábí u Sušice: nákladem JUC J. Šandy, 48 s.

Jurek, D., 2019. Eine kleine Kirche in Europa: die Tschechoslowakische Hussitische Kirche im Wandel zwischen Nationalkirche und europäischem kirchlichen Akteur, Göttingen: Vandenhoeck \& Ruprecht, 312 s.

Kadeř́vek, V. - Trtík, Z. 1982. Život a víra ThDr. Karla Farského, Praha: Ústřední církevní nakladatelství, 199 s.

Kalous, F., 1937. Dr. Karel Farský, vzor duchovního Církve československé, Náboženská revue Církve československé, 9, 1937, s. 97-103, 129-137.

Kaňák, M., 1951. Dr. Karel Farský. O životě a díle prvního patriarchy církve československé, Praha: Blahoslav, $123 \mathrm{~s}$.

Kobrlová, J., 2010. Karel Farský, první patriarcha Církve československé (husitské): věnováno 90. výročí vzniku Církve československé (husitské), Časopis Společnosti př́tel starožitností, 118, č. 3, s. 151-164.

Konečný, J., 1922. Československý katechismus - rozklad křest'anství. (Rozbor katechismu dr. Farského a Kalouse), Hradec Králové: Tiskové družstvo, $70 \mathrm{~s}$.

Kučera, Z., 1988. O teologickou totožnost církve československé husitské. Praha: Ústřední církevní nakladatelství, 134 s.

Lahodný, S., 1955. Farský a naše dny, Praha: Ústřední církevní nakladatelství, 98 s.

LA PNP Praha, f. B. Zahradník-Brodský, kart. 15 - dopis J. Žídka B. Zahradníkovi z 21. 8. 1920. [LA PNP, J. Žídek to B. Zahradník, August 21 $\left.{ }^{\text {st }}, 1920\right]$.

LA PNP Praha, f. B. Zahradník-Brodský, kart. 15 - dopis J. Žídka B. Zahradníkovi z 2. 12. 1920. [LA PNP, J. Žídek to B. Zahradník, Dezember $\left.2^{\text {nd }}, 1920\right]$.

LA PNP Praha, f. B. Zahradník-Brodský, kart. 15 - dopis J. Žídka B. Zahradníkovi z 4. 10. 1921. [LA PNP, J. Žídek to B. Zahradník, October $\left.4^{\text {th }}, 1921\right]$.

Marek, P., 2000. České schisma. Přispěvek k dějinám reformního hnutí katolického duchovenstva v letech 1917-1924, Olomouc

- Rosice: Gloria, 333 s.

Marek, P., 2005. Církevní krize na počátku prvni Československé republiky (1917-1924), Brno: L. Marek, $340 \mathrm{~s}$.

Marek, P., 2007. Emil Dlouhý-Pokorný. Život a pưsobeni katolického modernisty, politika a žurnalisty, Brno: Centrum pro studium demokracie a kultury, $370 \mathrm{~s}$.

Marek, P., 2010. Josef Žídek. Nástin života a díla reformního kněze, zakladatelské postavy pravoslavné církve na Moravě, Olomouc: Univerzita Palackého, 351 s.

Marek, P., Šmíd, M., 2013. Arcibiskup František Kordač. Nástin života a díla apologety, pedagoga a politika, Olomouc: Univerzita Palackého, $224 \mathrm{~s}$.

Marek, P., 2014. Př́pravy kzaloženi Církve československé (husitské) v letech 1918-1920. Kultúra pretrvá svojho tvorcu. Zborník venovaný 20. výročiu úmrtia Ladislava Hanusa, eds. Peter Zmátlo, Juraj Považan, Ružomberok: Verbum, s. 95-133.

Marek, P., 2015. Česká reformace 20. století? K zápasu Církve československé (husitské) o vizi moderního českého krest’anství $v$ letech 1920-1924, Olomouc: Univerzita Palackého, 384 s.

Marek, P., 2017. Bratři Bohumil a Isidor Zahradníkovi. Dva kněžské osudy na přelomu 19. a 20. století, Olomouc: Univerzita Palackého, $128 \mathrm{~s}$.

Marek, P., 2008. The „Eastern-Orthodox Crisis“ in the Czechoslovak Church Through the Eyes of the Old-Catholics: Cooperation or Merger? Reflections on the Corollary of Czech Catholic Modernism. Cosmas. Czechoslovak and Central European Journal, Vol. 21, Nr 2, p. 22-42.

Marek, P., 2018. Za lepši cirkví? K úsilí českého duchovenstva v 19. a na počátku 20. století modernizovat náboženský a církevni život. Modernizace církve. Od zrušení jezuitského řádu do II. vatikánského koncilu, ed. M. Vařeka, A. Zářický, Ostrava: Filozofická fakulta Ostravské univerzity, s. 123-137. $698 \mathrm{~s}$.

Marek, P., 2019. Biskup Gorazd (Pavlik). Životní přiběh hledání ideální církve pro 20. století, Olomouc: Univerzita Palackého,

Němec, L., 1968. The Czech Jednota, the Avant-Garde of modern clerical progressivism and unionism, Proceedings of the American Philosophical Society (Philadelphia), vol. 112, No. 1, s. 74-100.

Němec, L., 1975. The Czechoslovak Heresy and Schisma. The Emergence of a National Czechoslovak Church, Philadelphia: American Philosophical Society, $78 \mathrm{~s}$.

Obr, L., 2013. Tajemství Kristovy osoby a lidské spásy v myšleni Karla Farského, Olomouc: Teologická fakulta Univerzity Palackého, rkp. bakalářské diplomové práce, $72 \mathrm{~s}$.

Padesát let Československé církve. (Sborník studii pracovníků Husovy fakulty, věnovaný k půlstoletí CČs). [Skriptum Husovy čs. bohoslovecké fakulty], 1970; ed. M. Kaňák, Praha: Ústřední církevní nakladatelství, 188 s.

Pařík, R., Moje odpověd’ na Zasláno br. Farského v Českém zápase č. 77. Za pravdou, 1923, r. 3, č. 49, 6. 12., s. $314-317$.

Pešek, B., 1939. Dr. Karel Farský jako katolický kněz, Náboženská revue Církve československé, 11, 1939, s. 129-135, $217-221$.

Pešková-Kounovská, O., 1937. Farský žije: o zakladateli a prvním patriarchovi církve československé pro mládež k desetiletému výroči jeho smrti, Praha: Ústřední rada církve československé, $15 \mathrm{~s}$.

Plechatý, F., 1949. 30 let cirkve československé, Praha: Blahoslav, $16 \mathrm{~s}$.

Religion im Nationalstaat zwischen den Weltkriegen 1918-1939. Polen, Tschechoslowakei, Ungarn, Rumänien, 2002; eds. H.

Ch. Maner, M. Schulze Wessel, Stuttgart: Steiner, 219 s.

Rillichová, T., 2016. Osobnost Karla Farského v cirkevním životě Československa ve 20. letech 20. století, České Budějovice: Historický ústav filozofické fakulty JČU, rkp. diplomové práce, $102 \mathrm{~s}$.

Rutrle, O. a kol., 1954. Patriarcha Dr. Karel Farský - novodobý hlasatel Ježiše Krista, Praha: Ústřední církevní nakladatelství, $234 \mathrm{~s}$.

Salajka, M., 1970. Ekumenické kapitoly. Skriptum pro studijní účely Husovy čs. bohoslovecké fakulty. Praha: Ústřední církevní nakladatelství, $79 \mathrm{~s}$.

Salajka, M., 2007. Portrét Církve československé husitské, Praha: Blahoslav pro náboženskou obec Církve československé husitské v Praze 1 - Staré Město, $51 \mathrm{~s}$. 
Sbornik Dr. Karla Farského. Kniha vzpomínek, dojmů a úryvků z díla a života zakladatele církve československé, 1928; ed. F. Pokorný, Praha: Tiskové a nakladatelské družstvo CČS, $288 \mathrm{~s}$.

Schulze Wessel, M., 2009. Die Tschechoslowakische Hussitische Kirche, Handbuch der Religions-und Kirchengeschichte der böhmischen Ländern und Tchechiens im 20. Jahrhundert; Hrsg. von M. Schulze Wessel, M. Zückert, München: R. Oldenburg Verlag, s. 135-146.

Schulze Wessel, M., 2011. Revolution und religiöser Dissens. Der römisch-orthodoxe Klerus als Träger religiösen Wandels in den böhmischen Ländern und in Russland 1848-1922, München: Oldenbourg Verlag, 343 s.

Šmíd, M., 2013. Patriarcha Karel Farský: příspěvek k životopisu prvního patriarchy Církve československé v letech 1924-1927, Theologická revue, 84, č. 1, s. 28-47.

Šmíd, M., 2017. Čtvrtek 8. ledna 1920. Rubikon reformního katolicizmu?, Theologická revue, r. 88, č. 2, s. 137-153.

Tonzar, D., 2002. Vznik a vývoj novodobé husitské teologie a Církev československá husitská, Praha: Karolinum, $210 \mathrm{~s}$.

Urban, R., 1938. Die slawisch-nationalkirchlichen Bestrebungen in der Tschechoslowakei mit besonderer Berücksichtigung der tschechoslowakischen und der orthodoxen Kirche, Leipzig: Markert und Petters, $325 \mathrm{~s}$.

ÚAMCČSH Praha, sig. A IV-24, Korespondence R. Paříka, i. č. 30 - dopis biskupa Gorazda R. Paříkovi, 17. 7.1924 [ÚAMCČH, Gorazd to R. Pašek, 17 July 1924].

ÚAMCČSH Praha, sig. A II - 36, Korespondence K. Farského, dopis biskupa Gorazda K. Farskému, 7. 8. 1923. [ÚAMCČH, Gorazd to K. Farský, 7 August 1923].

ÚAMCČSH Praha, sig. A II - 36, Korespondence K. Farského, kopie dopisu K. Farského biskupu Gorazdovi, 18.8 .1924$. [ÚAMCČH, K. Farský to Gorazd, August $\left.18^{\text {th }}, 1924\right]$.

Učení náboženství křestanského. Přijato I. řádným sněmem církve československé dne 28. až 30. března 1931, 1948, Praha: Církev československá, $28 \mathrm{~s}$.

ZA Opava, pob. Olomouc, f. Olomoucká diecéze CČS, sig. 1-12/IC, dopis K. Farského Zemské radě starších na Moravě, 28. 2. 1921. [ZA, to the Elders Provincial Copuncil, February $\left.28^{\text {th }}, 1921\right]$.

Základy viry Církve československé husitské se stručným komentářem. Přijaté na 1. zasedáni VI. sněmu dne 17. řijna 1971 jako oficiální nauková norma ve zněni ..., 2014, Praha: Církev československá husitská, $182 \mathrm{~s}$.

\title{
РЕЗЮМЕ
}

\section{ПРАВОСЛАВНІ ПРО КАРЕЛА ФАРСЬКОГО. ЩОДО БОРОТЬБИ ЗА ТЕОЛОГІЧНУ ОРІЕНТАЦЮЮ ЧЕХОСЛОВАЦЬКОЇ ГУСИТСЬКОЇ ЦЕРКВИ У 20-х РОКАХ ХХ СТОЛІТТЯ}

\author{
Павел Марек \\ PhDr. PaedDr., Ph.D., професор, почесний професор кафедри історії філософського факультету \\ університету Палацького в Оломоуці
}

У 1920 р. спливло століття від «чеської схизми», якою вважають заснування наиіональноі Чехословачької гуситської иеркви. Вона виникла як результат реформаторського руху католицького духовенства після закінчення Великої війни і конституювання самостійної Чехословацької Республіки на уламках Габсбурзької імперії. Духовенство, незадоволене статусом католищької иеркви в монархії та деякими питаннями житття иеркви і священиків, що довго не вирімувалися, накреслило програму реформи католицькоі церкви у чеських землях. Його вимоги торкалися автономії иеркви, запровадження національної мови у богослужінні, демократизаиії устрою церкви та реформи целібату священиків. Після того як римська курія пропозииії відхилила, радикальне крило реформаторського руху вирішило иеркву залишити і конституювати наиіональну иеркву. Проте підготовка до їі створення була недостатньою, тому всі фундаментальні питання існування церкви, зокрема віровчення, були вирішені тільки після ії виникнення. Стосовно иього в иеркві склалося два напрями поглядів. Периий прагнув до прийняття віровчення східних иерков, другий, керований майбутнім патріархом Карелом Фарським, окреслив ідею сучасної иеркви ХХ століття. Між обома групами аж до 1924 р. точилася гостра ідеологічна боротьба за просування власної концепиії. Метою дослідження $\epsilon$ відображення поведінки та діяльності К. Фарського речниками православно орієнтованої фракиії церкви.

Ключові слова: Карел Фарський, Чехословаџька гуситська черква, римо-католиџька церква, православне віровчення, теологічний модернізм, реформа черкви, національна церква, чеські землі, 20-і рр. ХХ ст. 